\section{Jan Słomka}

Uniwersytet Śląski, Katowice

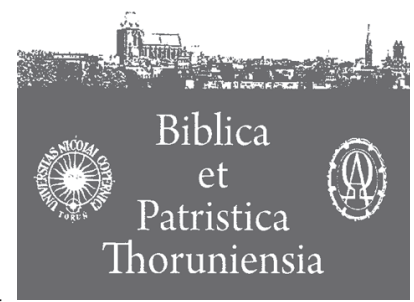

4 (2011) ISSN 1689-5150

\title{
(Nie)obecność idei upadku w preegzystencji w pierwszej homilii Orygenesa o Księdze Rodzaju
}

\section{The Idea of the Fall in Pre-existence and Its Absence in Origen's First Homily on the Book of Genesis}

Słowa kluczowe: Orygenes, Księga Rodzaju, preegzystencja, grzech pierworodny, egzegeza biblijna.

Key words: Origen, Book of Genesis, pre-existence, original sin, biblical exegesis.

$\mathrm{O}$

rygenes pierwszą homilię o Księdze Rodzaju poświęca biblijnym opisom stworzenia świata, czyli tekstowi Rdz 1,1-2,7. Wiemy, że Orygenes napisał także komentarz do Księgi Rodzaju, ale komentarz ten nie zachował się. Przypomnijmy zatem na wstępie, czym dla niego jest homilia i czym różni się od komentarza. Orygenes pisał o tym m.in. w 10. homilii o Księdze Rodzaju:

Musimy pominąć wiele problemów. Bo nie czas teraz na komentarze, pora na budowanie Kościoła Bożego i na pobudzanie leniwych i gnuśnych słuchaczy za pomocą przykładów świętych oraz za pomocą mistycznych objaśnień ${ }^{1}$.

A więc głównym celem głoszenia homilii jest "budowanie Kościoła”. W komentarzach, co możemy zobaczyć np. w zachowanym komentarzu do Listu do Rzymian, Orygenes stara się poruszyć wszystkie tematy i problemy wynikające z tekstu. W homiliach zaś dokonuje wyboru. Jest to wybór podyktowany właśnie wymogiem „budowania Kościoła”. Możnaby więc uznać, że w homiliach Orygenes pomija tematy kontrowersyjne, trudniejsze, a ogranicza się do zagad-

1 Homilia o Księdze Rodzaju 10,5, w: Orygenes, Homilie o Księgach Rodzaju, Wyjścia, Kapłańskiej, tłum. i opracowanie S. Kalinkowski, wstęp E. Stanula, Warszawa 1984, z. 1, s. 111. Dalej cytowana jako RdzHom. 
nień łatwiejszych. Jednak lektura jego homilii pozawala na postawienie tezy, że stosował on inne kryterium. Otóż, jak się wydaje, Orygenes nie unikał tematów trudniejszych, jak sam je nazwał „mistycznych objaśnień”, o ile tylko uznał, że są one ważne dla życia duchowego słuchaczy. Tak więc wstępnie możemy przyjąć, że wybór komentowanych w homiliach o Księdze Rodzaju tekstów oraz wybór podejmowanych wątków wynika nie tyle z unikania kontrowersji, co z uznania, że właśnie te, a nie inne, są najważniejsze dla umocnienia życia chrześcijańskiego. Przyjąwszy te wstępne założenia możemy przyjrzeć się jednemu z głównych tematów, jakie podjął Orygenes w pierwszej homilii o Księdze Rodzaju: człowiekowi jako istocie stworzonej przez Boga.

W typowy dla siebie sposób Orygenes wyróżnia w komentowanym tekście sens literalny i sens duchowy czyli alegoryczny. Jednak, w porównaniu z innymi homiliami, sens literalny jest omawianej przez nas homilii potraktowany wyjątkowo zdawkowo. Nie ma ani szerokich komentarzy na temat możliwości takiego, a nie innego przebiegu wydarzeń historycznych opisanych w tekście biblijnym. Takie obszerne komentarze znajdziemy np, w drugiej homilii o Księdze Rodzaju, gdzie Orygenes, zanim przejdzie do omawiania sensu duchowego, długo rozważa techniczne możliwości zbudowania statku o parametrach podanych przez tekst oraz pomieszczenia $\mathrm{w}$ nim zwierząt. W omawianej przez nas homilii nie ma również żadnego komentarza dystansującego wobec sensu literalnego. Orygenes, jak wiadomo, dopuszczał możliwość braku lub kompletnej niezrozumiałości sensu literalnego, defectus litterae ${ }^{2}$, jednak żadne tego typu zastrzeżenie odnośnie do tekstu literalnego nie pojawia się w omawianej homilii. Wręcz przeciwnie. Orygenes kilkakrotnie wspomina, że tekst literalny jest oczywisty, ale, poza jednym wyjątkiem, nie rozwodzi się nad nim. Ten wyjątek to zdanie o stworzeniu człowieka jako mężczyzny i kobiety. Powrócimy do niego w dalszej części naszego artykułu.

Jak już wspomnieliśmy, głównym tematem homilii jest człowiek: jego wewnętrzna struktura i miejsce w całym świecie stworzonym przez Boga, oraz wynikające $\mathrm{z}$ tego wezwania moralne i duchowe. Naszym zamiarem jest systematyczne przedstawienie tego tematu. Będzie nas szczególnie interesowało pytanie, na ile opis człowieka, jaki przedstawia Orygenes w tej homilii, uwzględnia teorię upadku w preegzystencji. Ta teoria, jak pisze Crouzel, „ma dla Orygenesa charakter hipotezy, wszelako hipotezy ulubionej, która cały czas

2 Zob. O zasadach 4,3,5: „Jeżeli jednak ktoś uważnie czyta Pismo, niewątpliwie niewątpliwie zawaha się przy wielu miejscach, czy ta, albo tamta historia ma być uważana za prawdziwą w dosłownym znaczeniu..... w: Orygenes, O zasadach, z j. łacińskiego i greckiego przełożył i opracował S. Kalinkowski, Wprowadzenie H. Pietras SJ, Kraków 1996, s. 358. 
kieruje jego myślą, nawet kiedy wprost jej nie przywołuje”3. Jak wiadomo teoria ta już w starożytności wywoływała gwałtowne polemiki, a i dzisiaj ciągle jest jednym z częściej podejmowanych problemów w ramach dyskusji na temat spuścizny teologicznej Orygenesa. Pierwszy rozdział Księgi Rodzaju wydaje się właśnie tym tekstem, w którym Orygenes będzie wskazywał na biblijne podstawy swojej hipotezy, albo po prostu, komentując go, będzie się do swojej hipotezy w jakiś sposób odnosił.

\section{Opis stworzenia jako opis struktury świata}

Przede wszystkim Orygenes łączy początek Księgi Rodzaju i początek Ewangelii Jana i podkreśla, że słowa „na początku” nie przedstawiają kolejności chronologicznej, ale wskazują na początek w sensie bytowym, jak byśmy to dzisiaj powiedzieli - ontologicznym. A zatem także kolejność stworzenia, z tym, że tylko w odniesieniu do pierwszego dnia, jest dla Orygenesa punktem wyjścia do przedstawienia struktury świata. Stworzenie na początku nieba oznacza, że fundamentem świata jest „substancja duchowa”, na której spoczywa Bóg. To stworzenie dokonuje się jeszcze przed stworzeniem czasu, który jest ściśle związany $\mathrm{z}$ istnieniem świata materialnego ${ }^{4}$. Poniżej, w sensie strukturalnym, znajduje się niebo - sklepienie niebieskie, czyli świat materialny, którego stwarzanie odbywa się już w upływającym czasie. Najniżej jest otchłań: Co istotne, otchłań została stworzona na początku, jeszcze przed rozdzieleniem światła i ciemności. Otchłań jest stworzona przez Boga i przeznaczona na mieszkanie dla demonów. Ale, jak możemy wnioskować z tekstu Orygenesa, demony zostaną wypędzone do niej później. Oczywiście diabeł, szatan i jego aniołowie są przedstawieni jako stworzenia Boże. Orygenes pisze o nich komentując Rdz $1,21,-22$, gdzie jest mowa o stworzeniu potworów morskich i istot pełzających. Symbolizują one właśnie diabła:

Może ktoś zapytać, dlaczego wielkie potwory morskie i płazy uznajemy za złe, a ptactwo za dobre, podczas, gdy o jednych i drugich powiedziano: „i ujrzał Bóg, że są dobre". Otóż dla świętych dobre są byty. z którymi walczą, [...] Dlatego właśnie o tym wszystkim Pismo powiada: „i ujrzał Bóg, że są dobre”.

3 H. Crouzel, Orygenes, przekład Janusz Margański, Bydgoszcz 1996 (dalej cytowane jako Crouzel), s. 277.

4 RdzHom 1,2, s. 22.

5 RdzHom 1,10, s. 30-31. 
Orygenes podkreśla tu rozróżnienie: rzekł Bóg - widział Bóg. Bóg widział, że były dobre, to znaczy zobaczył jakąś korzyść jaką przynosi aktualny stan tych istot, ale nie oznacza, że te istoty, a więc diabeł i jego aniołowie, stali się właśnie takimi z rozkazu Boga, na jego słowo. W ten sposób Orygenes łączy prawdę o tym, że wszystko, co stworzył Bóg jest dobre, z uznaniem istnienia diabła, który czyni zło. Tutaj Orygenes podkreśla cechę stworzenia, którą moglibyśmy nazwać autonomią bytów stworzonych: stworzony przez Boga diabeł istnieje pomimo, że czyni zło i Bóg pozwala mu czynić zło. Tak samo Orygenes uznaje wolność, samodzielność człowieka wobec Boga za realną i to za fundamentalną cechę człowieka jako stworzenia Boga.

\section{Wyjątkowość człowieka}

Wyjątkowość człowieka w całym stworzeniu jest jednym z najważniejszych, jeżeli nie najważniejszym, motywem w omawianej homilii Orygenesa. Komentując słowa z Księgi Rodzaju 1,26: „Uczyńmy człowieka na nasz obraz podobnego nam”. Orygenes najpierw koncentruje się na dwóch pierwszych: „uczyńmy człowieka". Wskazuje, że kolejne elementy świata stworzonego powstają na rozkaz Boży, natomiast tylko trzy stworzenia są „,dziełem samego Boga”, w tym sensie że nie są efektem rozkazu, ale zostały niejako osobiście wykonane. Są to: niebo i ziemia, wielkie światła, czyli słonce, księżyc i gwiazdy oraz właśnie człowiek. Następnie pisze:

Oceń na tej podstawie, jaka jest wielka godność człowieka: zostaje on zrównany $\mathrm{z}$ tak wielkimi i tak ważnymi elementami. Posiada godność nieba, bo obiecano mu „królestwo niebieskie” (Mt 5,10). Posiada też godność ziemi, ponieważ ma nadzieję, że wejdzie do dobrej ziemi, do „ziemi płynącej mlekiem i miodem” (Wj 3,8). Posiada też godność słońca i księżyca, bo obiecano mu, iż będzie „jaśniał jak słońce w królestwie Boga" (Mt 13,43) ${ }^{6}$.

Dodajmy, że w interpretacji alegorycznej Orygenesa niebo i ziemia oznacza całość stworzenia, słońce - Chrystusa, księżyc - Kościół, a gwiazdy to święci Starego Testamentu i „wszyscy, którzy podobali się Bogu” (por. Hbr 11,5)7.

Wyjątkowość człowieka wyraża się również przez to, że człowiek obejmuje w sobie wszystkie wymiary rzeczywistości stworzonej:

6 RdzHom 1,112, s. 33.

7 RdzHom 1,7, s. 27. 
Owym pierwszym niebem, które nazwaliśmy niebem duchowym jest nasz umysł, który też jest duchem, a więc jest to nasz człowiek duchowy, który widzi i ogląda Boga. Natomiast niebem cielesnym, które zwie się sklepieniem, jest nasz człowiek zewnętrzny, który patrzy w sposób cielesny.

A zatem jak sklepienie zostało nazwane niebem, ponieważ rozdziela ono wody, które są ponad nim, od tych, które są pod nim, tak też i człowiek ustanowiony w ciele, jeżeli potrafi dzielić i rozróżniać wyższe wody, które są ponad sklepieniem, od tych, które są pod sklepieniem sam zostanie nazwany niebem, to znaczy „człowiekiem niebieskim”, zgodnie z wypowiedzią Pawła Apostoła: „a mieszkanie nasze jest w w niebie" (Flp 3,20) ${ }^{8}$.

Cały świat widzialny, łącznie $\mathrm{z}$ widzialnym sklepieniem niebieskim symbolizuje „człowieka zewnętrznego”. Również w tym „zewnętrznym” wymiarze człowiek jest koroną całego stworzonego świata widzialnego. Orygenes pisze:

Skoro już wszystkie rzeczy widzialne został stworzone na rozkaz Boga przez Jego Słowo i skoro ten ogromny widzialny świat został urządzony, a równocześnie sens alegoryczny wskazuje, jakie elementy mogą przyozdobić mniejszy świat, czyli człowieka, to wówczas człowiek zostaje stworzony, jak to zapisano w następnym rozdziale?

Z całą pewnością chodzi tutaj o stworzenie człowieka zewnętrznego, cielesnego. albowiem stworzenie człowieka duchowego, niebieskiego, jako że jest on istotą duchową, odbyło się przed wszelkim czasem. Prawdopodobnie Orygenes odnosi się tutaj do słów z Rdz 2,7, o ulepieniu człowieka z mułu ziemi.

Jednak wyjątkowość i wielka godność człowieka najdobitniej została przedstawiona przez Orygenesa w komentarzu do słów o człowieku jako „stworzonym na obraz Boży". Orygenes pisze:

W stworzeniu człowieka dostrzegam jednak pewien element jeszcze znamienitszy, bo nigdzie indziej nie znajduję stwierdzenia: „I stworzył Bóg człowieka, na obraz Boga go stworzył" (Rdz 1,27). Nie znajdujemy, iżby coś podobnego zostało zapisane w odniesieniu do nieba, ziemi, słońca czy księżyca.

Następnie precyzuje, że obrazem Boga jest człowiek wewnętrzny, gdyż istota cielesna nie może zawierać w sobie obrazu Boga. Do człowieka cielesnego odnosi drugi opis stworzenia $(\operatorname{Rdz} 2,7)$ i podkreśla, że jest tam mowa nie o stworzeniu, ale o „ulepieniu”: człowiek został uformowany z mułu ziemi.

8 RdzHom1,2, s. 22-23.

9 RdzHom 1,11, s. 32. 
„Ten zaś - pisze dalej - który został stworzony na obraz Boga, to nasz człowiek wewnętrzny - niewidzialny, niecielesny, niezniszczalny i nieśmiertelny, w takich bowiem przedmiotach słusznie można rozpoznać obraz Boga"10. Mamy więc tutaj odwołanie do orygenesowej koncepcji drugiego stworzenia, stworzenia świata zmysłowego, a zatem także „człowieka zewnętrznego”. Jednak podkreślanie, że obrazem Boga jest człowiek wewnętrzny nie jest powiązane ze stwierdzeniem, że stworzenie człowieka zewnętrznego jest efektem upadku, grzechu, ale jest elementem polemiki z tymi, którzy pojmują Boga materialnie $\mathrm{i}$ interpretują dosłownie teksty biblijne przedstawiające Boga jako zasiadającego na tronie, jakby było on po prostu ogromną postacią: tak wielką że sięgającą od widzialnej ziemi do widzialnego nieba.

Orygenes następnie szeroko omawia jeden ze swoich ważnych tematów: otóż człowiek jest właściwie obrazem obrazu, bo jedynym obrazem Boga jest Chrystus-Zbawiciel, ale ten temat nie jest dla nas na tyle istotny, aby go tutaj szerzej komentować ${ }^{11}$.

\section{Człowiek zewnętrzny i wewnętrzny, symbolika ziemi i wody}

Woda ma dla Orygenesa symbolikę podwójną. Jest symbolem zarówno życia jak i śmierci, występku, grzechu. Takie podwójne znaczenie wody znajduje swoje oparcie w opisie rozdzielenia wód na te, które są nad niebem i te, które są pod niebem. „Wody, które są pod niebem”, to grzechy i występki naszego ciała, symbolizowanego przez stworzoną ziemię. Dlatego odsunięcie tych wód i wyłonienie się suchej ziemi oznacza w sensie duchowym wezwanie do do odrzucenia występków ciała. Wtedy ciało zostanie oczyszczone - stanie się „suchą powierzchnią". Ale ta powierzchnia nie powinna pozostać sucha, ale zostaje przez Boga nazwana „ziemią”, a więc staje się żyzna, otrzymuje od Boga możliwość, aby przynosić owoc $\mathrm{w}$ Bogu. Natomiast jeżeli ktoś $\mathrm{z}$ własnej winy pozostaje „suchy” i nie przynosi żadnego owocu, lecz tylko „osty i ciernie” (Rdz 3,18) - jego życie staje się zupełnie bezpłodne i jest tylko „pożywką ognia (Iz 19,9).

\section{Ziemia jako człowiek zewnętrzny}

Ziemia jest konsekwentnie przedstawiana przez Orygenesa jako symbol człowieka zewnętrznego.

10 Tamże.

11 RdzHom 1,13, s. 34-35. 
W ramach takiej interpretacji alegorycznej Orygenes komentuje opis płodności ziemi:

A więc i my powinniśmy w taki właśnie sposób wydawać owoc i mieć $\mathrm{w}$ sobie nasiono, to znaczy posiadać w swym sercu nasiona wszelkich dobrych uczynków i wszelkich cnót; jeżeli tkwić one będą w naszych umysłach, to dzięki nim będziemy dokonywać wszystkich uczynków, jakie się nam przydarzą, zgodnie z wymogami sprawiedliwości. One to, uczynki nasze, są owocami tego nasienia pochodzącymi „Z dobrego skarbca naszego serca” (Łk 6,45) $)^{12}$.

Według tego samego klucza Orygenes komentuje tekst Rdz 1,29-3013:

I rzekł Bóg: „Oto dałem wam na pokarm wszelką roślinę, która jest po całej ziemi i wszelkie drzewo, które ma w sobie owoc $\mathrm{z}$ nasionami - to będzie pokarmem dla was i dla wszystkich dzikich zwierząt ziemi, dla wszystkich ptaków niebieskich i dla wszystkich płazów, które pełzają po ziemi i które mają w sobie pierwiastek życia”.

Rozwijając egzegezę duchową Orygenes interpretuje rośliny, które pozwolono zjadać ludziom, jako namiętności cielesne. Fakt, że ludzie otrzymali je na pokarm oznacza, że same namiętności nie są złe, a nawet, jako pokarm, są niezbędnym elementem cielesności człowieka. Natomiast tylko od człowieka zależy, ku czemu je obróci. Orygenes podaje przykład gniewu: może być gniew sprawiedliwy, skierowany przeciw grzechowi, lub gniew niesprawiedliwy, karający niewinnych. Tak samo pożądliwość skierowana ku Bogu może prowadzić nas w górę, a skierowana ku sprawom ziemskim prowadzi nas do grzechu. Wniosek moralny jest taki, że również namiętności cielesne mogą stać się dla nas pokarmem w sensie duchowym, nie trzeba ich zupełnie odrzucań jakoby były złe same sobie, ale panować nad nimi i kierować je we właściwą stronę.

Orygenes wskazuje, że te same rośliny są pokarmem nie tylko ludzi, ale wszystkich zwierząt. Jednak tylko człowiek usłyszał słowa Boga: „Dałem wam je na pokarm”. Zwierzęta otrzymały po prostu ten pokarm. Orygenes na tej podstawie pokazuje, że cielesność ludzi i zwierząt oraz związane z nią namiętności zmysłowe są w zasadzie takie same. Człowiek zewnętrzny, zmysłowy ma taką samą budowę, jak zwierzęta. Ale u zwierząt te zmysłowe namiętności po prostu są częścią ich życia, natomiast tylko człowiek otrzymał zadanie, aby rozum, człowiek wewnętrzny, panował nad nimi. Oczywiście w tym samym

12 RdzHom 1,4, s. 25.

13 Zob. RdzHom 1,17, s. 38n. 
duchu Orygenes interpretuje alegorycznie nakaz, by człowiek panował nad wszystkimi stworzeniami na ziemi ${ }^{14}$.

Symbolika ziemi, jako części zmysłowej człowieka powraca też przy komentowaniu wersetów Rdz 1,24-515: „I rzekł Bóg: „niechaj ziemia wyda istoty żywe wedle ich gatunku, czworonogi płazy i dzikie zwierzęta ziemi według ich gatunku”. I stało się tak. I stworzył Bóg dzikie zwierzęta ziemi według ich gatunku oraz wszelkie płazy ziemi wedle ich gatunku. I ujrzał Bóg, że są dobre”. Otóż wszystkie stworzenia pochodzące z ziemi, to „poruszenia naszego zewnętrznego człowieka, czyli człowieka cielesnego i ziemskiego". A więc symbolizują one namiętności i wszystkie pokusy zmysłowe. Te wszystkie poruszenia należy poskromić i zadać im śmierć. Orygenes przywołuje tutaj słowa św. Pawła: „Zadajcie śmierć członkom waszym, które są na ziemi...” (Rz 3,5).

\section{Woda jako człowiek wewnętrzny}

Jak już wspomnieliśmy Orygenes, wychodząc od opisu rozdzielenia wód, nadaje wodzie dwojakie znaczenie symboliczne. Wody dolne oznaczają grzech i śmierć, natomiast wody górne, które są nad niebem, to symbol umysłu, człowieka wewnętrznego. Orygenes rozwija tę symbolikę przy okazji każdego tekstu biblijnego, który mówi o tym, co na rozkaz Boży powstaje z wody.

W Księdze Rodzaju 1,20 czytamy: „I rzekł Bóg: Niechaj wody wydadzą płazy spośród istot żyą̨cych oraz ptactwo fruwające ponad ziemią na sklepieniu nieba. I stało się tak". Orygenes komentuje ten tekst duchowo:

Zastanówmy się jednak, w jaki sposób to samo dzieje się na sklepieniu naszego nieba, to znaczy w trwałym elemencie naszego umysłu, czy serca. Według mnie, skoro nasz umysł został oświecony przez Chrystusa - nasze słońce, to z kolei umysł otrzymuje nakaz aby $\mathrm{z}$ wód, które są w nim, wywiódł płazy i fruwające ptaki, to znaczy wydał dobre albo złe myśli po to, żeby zaistniał podział między dobrymi i złymi myślami, które przecież, jedne i drugie, z serca pochodzą. Wszak z serca naszego, jakby z wód wydobywają się zarówno dobre, jak i złe myśli. My jednak na słowo i rozkaz Boga wydobywamy jedne i drugie myśli na widok i na sąd Boży po to, abyśmy dzięki Jego oświeceniu mogli oddzielić zło od dobra, to znaczy, byśmy odrzucili od siebie to, co pełza po ziemi i co niesie ze sobą ziemskie troski ${ }^{16}$.

\footnotetext{
14 Zob. RdzHom 1,12, s. 32.

15 Zob. RdzHom 1,11, s. 31n.

16 RdzHom 1,8, s. 29.
} 
Tak więc opis stworzenia stał się dla Orygenesa kanwą do przedstawienia człowieka, jako istoty duchowo-cielesnej: człowieka zewnętrznego i wewnętrznego. To z kolei jest punktem wyjścia do pouczeń i zachęt moralno-duchowych. $\mathrm{Na}$ uwagę zasługuje znamienna różnica między stworzeniami, jakie wydała ziemia, a stworzeniami wyprowadzonymi z wody. Otóż, pisując ciało - ziemię i rodzące się z niej różne stworzenia, Orygenes stwierdza, że gdy ziemia rodzi osty - jest to świadectwo bezpłodności, tego, że nie przyjęła od Boga ożywczej wody, dzięki której mógł stać się żyzną ziemią. Podobnie są przedstawione dzikie zwierzęta i płazy ziemi. Natomiast umysł ludzki jest wezwany do wydawania z siebie zarówno ptaków, jak i płazów, a więc zarówno myśli dobrych jak i przyziemnych. Samo wydobycie z siebie myśli przyziemnych nie jest złe, ale dobre. Dopiero potem, co więcej, właśnie dzięki temu, że zostały one z umysłu wydobyte na widok Boży, mogą zostać osądzone i odrzucone. A więc jeżeli chodzi o cnoty i uczynki - człowiek nie powinien dopuszczać do siebie nic im przeciwnego, pozwalać, aby na ziemi jego ciała wyrosły jakiekolwiek osty. Jeżeli zaś chodzi o myśli - sytuacja jest zupełnie inna: tu człowiek powinien wydobywać z siebie także myśli przyziemne - płazy.

Ta druga część jest niewątpliwie inspiracją dla duchowej nauki Ewagriusza z Pontu o ośmiu duchach zła. Ewagriusz pisząc o duchach zła czyli złych myślach podkreślał, że sam fakt, iż one przychodzą do nas, czy powstają w nas, nie jest zły. Złe jest dopiero pozawalanie, aby te myśli w nas trwały ${ }^{17}$.

\section{Stworzenie mężczyzny i kobiety}

Jedyny fragment $\mathrm{z}$ opisu stworzenia, przy którym Orygenes poświęcił więcej uwagi sensowi literalnemu, to tekst Rdz 1,27-28: „Stworzył ich Bóg jako mężczyznę i kobietę i pobłogosławił im Bóg mówiąc: „Rośnijcie i rozmnażajcie się, i napełniajcie ziemię, a panujcie nad nią".

Orygenes komentuje ten tekst następująco:

Warto, jak sądzę, zastanowić się w tym miejscu zgodnie z sensem literalnym, dlaczego przed opisem stworzenia kobiety Pismo powiada: „Stworzył ich Bóg jako mężczyznę i kobietę". Być może - takie jest moje zdanie - ze względu na błogosławieństwo, które Bóg wygłosił: „Rośnijcie i rozmnażajcie się, i napełniajcie ziemię, oraz w przewidywaniu tego, co miało nastąpić, powiedziano: „Stworzył ich

17 Ewagriusz, O praktyce [ascetycznej] 6, w: Ewagriusz z Pontu, Pisma ascetyczne, t. 1, przekład: K. Bielawski, M. Grzelak, E. Kędziorek, L. Nieścior, A. Ziernicki, wstęp i opracowanie: L. Nieścior, Kraków 1998, s 206-207. 
jako mężczyznę i kobietę". Bo tym sposobem człowiek widząc, iż zdolność wzrostu i rozmnażania jest skutkiem tego, iż dodano mu kobietę, mógł pokładać pełniejszą nadzieję w błogosławieństwie Bożym. Gdyby wszak Pismo powiedziało: „Rośnijcie i rozmnażajcie się, i napełniajcie ziemię, a panujcie nad nią”, a nie dodało zwrotu „stworzył ich jako mężczyznę i kobietę” to człowiek mógłby zwątpić w błogosławieństwo Boże tak, jak Maryja, która w odpowiedzi na błogosławieństwo wypowiedziane przez anioła rzekła: „Jakże się to stanie, skoro nie znam męża?”(Łk 1,34) ${ }^{18}$.

Przede wszystkim zwróćmy uwagę na charakterystyczny element orygenesowej egzegezy: sens literalny to sens historyczny, a więc kolejność zdarzeń opisanych w Piśmie jest tu istotna. Jak bowiem łatwo stwierdzić, w ramach egzegezy duchowej Orygenes nie przywiązuje wagi do kolejności stwarzania i nie stanowi to dla niego, oprócz już wspomnianego dnia pierwszego, istotnej przesłanki do wydobywania $\mathrm{z}$ opisu stworzenia sensów duchowych i zachęt moralnych.

Natomiast $\mathrm{w}$ omawianym tekście właśnie kolejność stwarzania i przestawienie w logice tejże kolejności - zanim zostanie stworzona kobieta, już jest mowa o człowieku jako mężczyźnie i kobiecie - staje się istotnym punktem wyjścia do rozważań Orygenesa. wniosek, jaki wyprowadza Orygenes z tego tekstu można przedstawić następująco: od samego początku Bóg zamierzył stworzenie człowieka jako mężczyzny i kobiety. Tę pierwotność Bożego zamiaru Orygenes podkreśla jeszcze dalej pisząc, że"człowiek został stworzony harmonijnie i w stosownym związku"19. Co więcej, od samego początku stworzenie człowieka jako mężczyzny i kobiety było związane z błogosławieństwem płodności. Orygenes nie czyni najmniejszych aluzji, jakoby współżycie cielesne mężczyzny i kobiety było czymś późniejszym, wynikającym z grzechu. Wręcz przeciwnie, wydaje się, że polemizuje z twierdzeniami, jakoby błogosławieństwo Boże nie obejmowało rozmnażania się i wszystkiego, co jest z tym związane, a więc współżycia cielesnego.

Ciekawe jest zestawienie tego tekstu Orygenesa $\mathrm{z}$ analogicznym tekstem Augustyna. Otóż Augustyn swoje dzieło „Wartości małżeństwa” rozpoczyna od egzegezy początku Księgi Rodzaju. Generalnie w tej egzegezie wiele wagi przywiązuje do upadku Adama i Ewy, jako chwili, w której został zmieniony początkowy zamysł Boży. Od początku bowiem Bóg zamierzył, według Augustyna, wspólnotę mężczyzny i kobiety, i ich związek, a może nawet i posiadanie potomstwa. Ale współżycie cielesne mężczyzny i kobiety, także w małżeństwie,

18 RdzHom 1,14, s. 36-37.

19 Tamże, s. 15. 
pojawiło się dopiero po upadku. Augustyn pisze wprost: „Gdyby nasi rodzice nie zgrzeszyli, mieliby dzieci w jakiś inny sposób, nie współżyjąc ze sobą"20.

\section{Podsumowanie: a co z hipotezą upadku w preegzystencji?}

Jak się okazuje w homilii Orygenesa poświęconej opisowi stworzenia nie znajdujemy w zasadzie żadnych nawiązań do teorii upadku w preegzystencji. A więc, aby opisać człowieka żyjącego na ziemi, jego status jako stworzenia Bożego, istoty cielesno-duchowej i wyprowadzić z takiego opisu wezwania moralno-duchowe, Orygenes wcale nie potrzebuje tejże teorii upadku w preegzystencji. Również cielesność człowieka i wszystkie związane z nią uwarunkowania naszego ziemskiego życia zostają wyprowadzone z biblijnego opisu stworzenia, bez odwoływania się do upadku Adama i Ewy. Wyraźnie zaznaczony podział na człowieka wewnętrznego, duchowego, oraz zewnętrznego, zmysłowego, jest wpisany w całą strukturę homilii. Ale motyw podwójnego stworzenia człowieka, najpierw duchowego, a potem cielesnego, zmysłowego, nie jest jakoś szczególnie uwypuklony. Oczywiście ten motyw pojawia się, ale służy on przedstawieniu struktury świata i człowieka - jest to struktura, w której podstawą jest „substancja duchowa”. Służy on przede wszystkim polemice $\mathrm{z}$ twierdzeniami, jakie pojawiały się także wśród chrześcijan, jakoby Bóg miał naturę materialną. Zupełnie nie pojawia się w homilii pytanie o powód drugiego stworzenia, stworzenia całego świata zmysłowego i człowieka zmysłowego - cielesnego. A przecież to właśnie tutaj moglibyśmy spodziewać się nawiązania do teorii upadku w preegzystencji, wszak to właśnie ten upadek miał być przyczyną stworzenia świata zmysłowego ${ }^{21}$.

Należy więc postawić pytanie jakie mogą być powody tej nieobecności hipotezy upadku w preegzystencji w tekście, w którym można się było spodziewać jej znaczącej obecności.

Pierwszą hipotezą, jaka się nasuwa, jest ewolucja poglądów Orygenesa. O zasadach, w którym to dziele najobszerniej pisał o upadku w preegzystencji, było pisane ok 220 roku w Aleksandriii ${ }^{22}$, a homilie były spisywane w Cezarei, gdy Orygenes miało około 60 lat, a więc w latach czterdziestych trzeciego

20 św. Augustyn, Wartości małżeństwa 2,2; w: Pisma świętego Augustyna o małżeństwie i dziewictwie, przekład i komentarz, redakcja ks. A. Eckmann, Wartości małżeństwa przełożył ks. W. Eborowicz, Lublin 2003, s. 76.

21 Szerzej na temat stworzenia świata zmysłowego i upadku w preegzystencji jako powodu tego stworzenia patrz: Coruzel, s. 286-290.

22 Zob. O zasadach, Wstęp autorstwa H. Pietrasa, s. 6. 
wieku ${ }^{23}$. A więc między napisaniem tych tekstów upłynął okres ponad dwudziestu lat. Co prawda u Orygenesa nie ma wyraźnie zaznaczonej ewolucji poglądów, ale można zauważyć, choćby po samej datacji dzieł, że z biegiem lat myślenie typowo biblijne coraz bardziej dominowało nad wpływami platońskimi. Być może z biegiem czasu Orygenes bynajmniej nie rezygnując z hipotezy preegzystencji, przyznawał jej coraz mniejsze znaczenie.

Nie ulega wątpliwości, hipoteza upadku w preegzystencji była nie tylko istotnym elementem polemiki z gnostykami, ale też niemal koniecznym intelektualnie wyjaśnieniem, które pozwalało na wyjaśnienie nierówności początkowego stanu człowieka bez jednoczesnego podważania sprawiedliwości Boga i równości wszystkich ludzi w stworzeniu. Z pewnością Orygenes nigdy tej swojej ulubionej hipotezy nie odrzucił. Ale omawiana przez nas pierwsza homilia o Księdze Rodzaju pozwala postawić hipotezę, że że teoria upadku $\mathrm{w}$ preegzystencji funkcjonuje tylko w niektórych obszarach jego myśli. Upadek w preegzystencji, jeżeli można tak powiedzieć, nie stał się dla Orygenesa kluczem interpretacyjnym do diagnozowania aktualnego stanu człowieka i jego relacji do Boga. Upadek ten nie zniszczył wolności człowieka, jego zdolności zwracania się ku Bogu i dążeniu do Niego. Można dodać, że jego druga homilia o Księdze Rodzaju jest już poświęcona arce Noego, a więc nie ma osobnej homilii o upadku Adama i Ewy. Nie mamy powodu przypuszczać, że taka homilia istniała i została zagubiona.

Jeżeli przyjąć taki wniosek, to trzeba stwierdzić, że istnieje znacząca różnica między hipotezą Orygenesa dotyczącą upadku w preegzystencji, a koncepcją grzechu pierworodnego, jaką wypracował Augustyn. U Augustyna właśnie grzech pierworodny jest jednym ze znaczących uwarunkowań składających się na diagnozę aktualnego stanu człowieka: to właśnie na skutek tego grzechu człowiek jest oddzielony od Boga i pozostaje w stanie całkowitej niemożności zwrócenia się ku Bogu o własnych siłach. Grzech pierworodny według Augustyna dotknął każdego człowieka i tak osłabił jego dobrą wolę, że sama z siebie nie jest zdolna zwrócić się ku Bogu. U Orygenesa, przynajmniej w omawianej przez nas homilii, żadna $\mathrm{z}$ takich konsekwencji upadku w preegzystencji nie została przedstawiona.

23 RdzHom, Wstęp, s. 7. 


\section{Summary}

The idea of the fall in pre-existence is one of Origen's best-known concepts. According to his hypothesis, God created all spiritual beings, rational and free, before the beginning of time. Those beings turned away from God and fell as a result. Their fall gave rise to the creation of the material world. Origen thus explains the fact that, even before they deserve to be punished or rewarded, people do not have equal conditions for living from the moment they are born. The idea of the fall in pre-existence helped Origen to reconcile that inequality with the recognition of God's omnipotence and justice. It also provided a vital point for his polemics against the Gnostics.

The theory, however, does not appear in his first homily on the Book of Genesis, providing a commentary on the biblical description of creation - a text where a reference to the fall in pre-existence would be well-grounded. It praises the creation of the material world and man as the crown of creation. The homily presents the distinction between the inner and the outer man, which is typical of Origen, however, it contains no hints to the fall as the cause for creating the sensuous world and the outer man.

One of the reasons for such absence might be that Origen did not perceive his theory as vital for the spiritual growth of Christians, he only used it as an element of polemics with the Gnostics. As Origen stressed himself, his thought was always open and searching, thus such inconsistency and selectivity of his approach to the idea of the fall in pre-existence does not seem unusual. If this is a correct conclusion, then the idea of the fall in pre-existence is distinctly different from the Western concept of the original sin. 